\title{
Design Drawing As a Tool to Communicate Business Opportunities
}

\section{David Sukardi Kodrat}

Faculty Management and Business, Magister Management Program, Universitas Ciputra, Surabaya, Indonesia

\begin{abstract}
The purpose of this study was to examine design drawings as a means to communicate ideas to others in forms and symbols that are simple and easily understood by users.

Data gathering is done by mapping design by photographing designs, design trips by tracking previous designs, design journals by making visual design diaries, interviewing extreme users with people who really know and really do not know, and unfocused groups with various group of people.
\end{abstract}

The stages of analysis are done by finding references, drawing analogies and making evaluations.

Corresponding Author:

David Sukardi Kodrat

david.kodrat@ciputra.ac.id

Received: 30 December 2019

Accepted: 29 January 2020

Published: 6 February 2020

Publishing services provided by

Knowledge E

(c) David Sukardi Kodrat. This article is distributed under the terms of the Creative Commons Attribution License, which permits unrestricted use and redistribution provided that the original author and source are credited.

Selection and Peer-review under the responsibility of the 6 th ICOEN 2019 Conference Committee.
G OPEN ACCESS
The results of this study prove that the drawing design process can be used as a tool to communicate business opportunities for loafer shoes, monk strap shoes and boots.

Keywords: Design Drawing, Business Opportunities Communication, Design, Drawing and Interpretation

\section{Introduction}

The drawing design strongly supports problem solving activities. This activity involves reasoning to express ideas, verify and evaluate proposals, and ultimately take action by making decisions [1]. For designers, drawing is a means and spontaneous sign made on paper [2]. During sketching, use partial notes of designer thinking [3].

Most designers sketch initial design ideas in pencil. Sketching is the fastest and most direct way to produce visual representations of ideas [4]. The ambiguity of free hand sketching creates many interpretations. Thus it will stimulate the production of more alternative designs. Drawing and linkage activities initiate designers to recognize new interpretations of the alternatives they propose. Designers find visual analogies, remember relevant examples, and find new shapes based on previously unknown geometric configurations in their sketches by drawing and seeing [5].

Decision making is a scientific discipline that focuses on alternative evaluation processes for alternative selection processes and finding the best solutions. Design is a 
tool for solving unpredictable problems. The design process can produce the latest leap of solutions and create new conditions altogether [3]. The research objective is to prove design drawing is a tool to communicate business opportunities

\section{Methods and Equipment}

This type of research is a case study. The informants were footwear craftsmen who had participated in the training using purposive random sampling as a sampling technique.

The data collection techniques used are as follows. First, DESIGN MAPPING is photographing designs that refer to similarities in the previous design domain. Second, TRAVEL DESIGN is tracking all designs in the previous design domain. Third, JOURNAL DESIGN is to make a visual design diary. Fourth, EXTREME USER INTERVIEW is to talk to people who really know or don't know anything about a product or service and evaluate the experience when they use it. Storytelling method is a method commonly used by persuading people to tell personal stories about their experiences using the product. Fifth, UNFOCUS GROUPS is interviewing various groups of people to explore ideas.

The following stages of the design drawing process [6]:

a. Stage of finding references

b. Stage of drawing an analogy

c. Stage of making an evaluation

\section{Results}

Drawing design programs have the purpose of simplifying the communication process of footwear design ideas from abstract forms converted into simple and visible forms and symbols [4]. Another goal is to learn to find various models that have been created so that they can create new design models [1]. This footwear model development program follows the design drawing model.

\subsection{Stage of finding references}

\subsubsection{LOAFERS SHOES}

\subsubsection{MONK STRAP SHOES BOOTS}




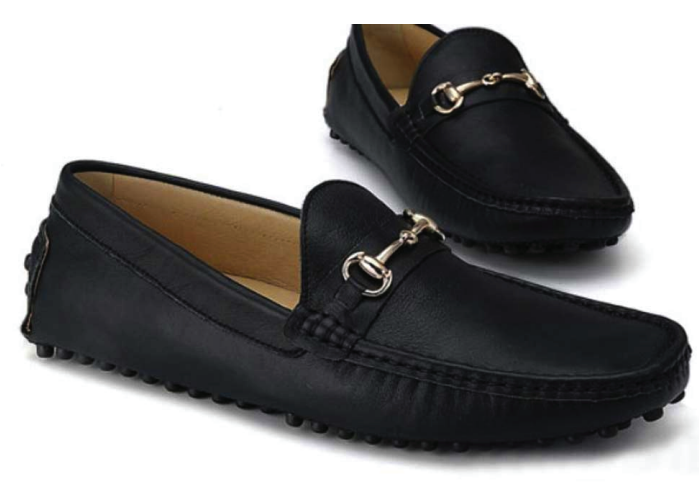

Figure 1: Loafers Shoes (Source: [7]).

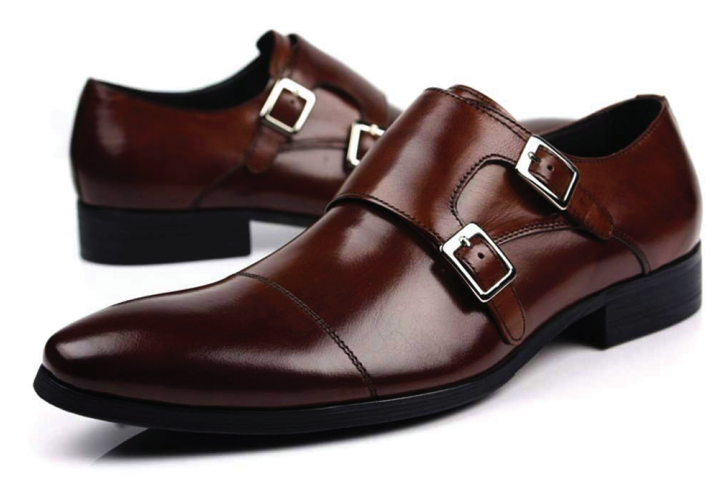

Figure 2: Monk Strap Shoes (Source: [7]).

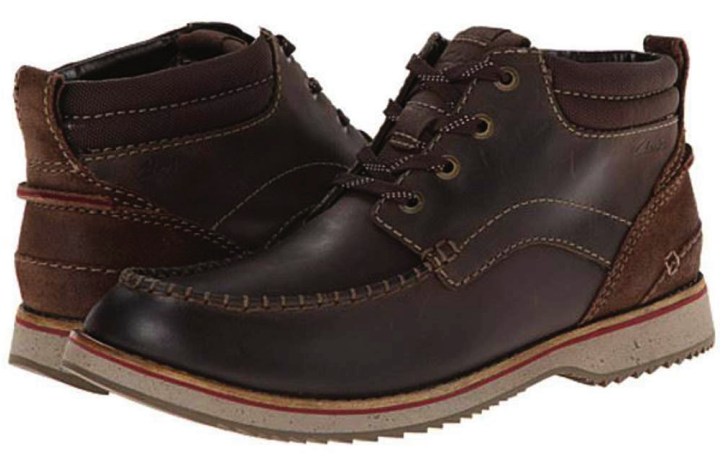

Figure 3: Boots (Source: [7]).

\subsection{The stage of drawing analogies and evaluations}

Figure 4 shows loafer shoes with design specifications used to communicate emerging ideas so that they can be easily understood by users before they are made prototypes. Instead of shoelaces, leather is used that functions like a buckle. 


\section{Pembuatan Desain Komputer " DS 01 "}

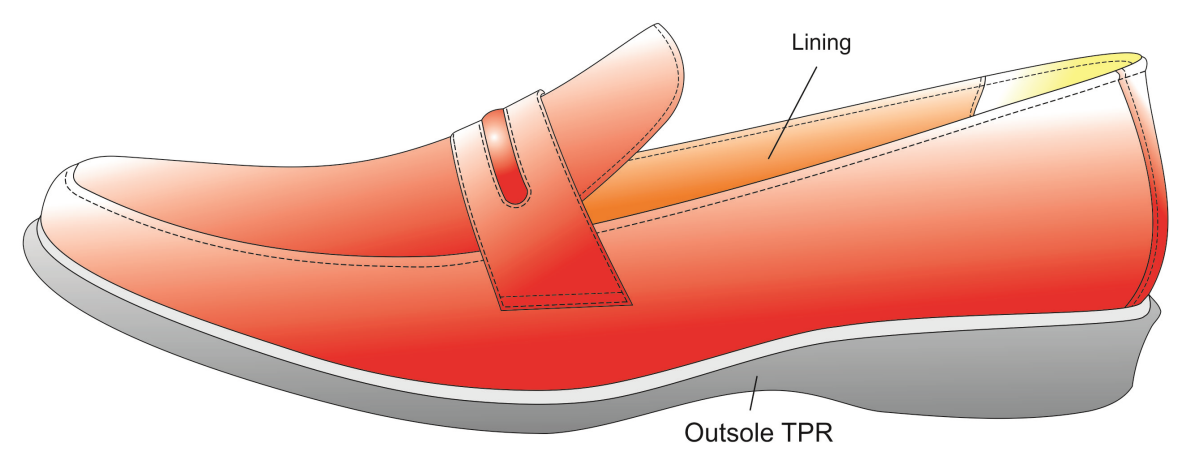

Spesifikasi desain " DS 01 ", antara lain :

1) Bahan upper, memakai kulit sapi jenis finish warna merah

2) Bahan Lining ( lapis dalam sepatu )

- Bagian depan kain kaos

7) Tamsin (Plat besi)

- Bagian belakang memakai bahan imitasi diping

3) Bahan insole

- Bagian atas texson dengan lapis kain kaos

- Bagian bawah keras TW

- Bagian alas sepatu memakai bahan sofi dilaminating

spon agar lebih lembut dan nyaman

4) Outsole memakai jenis sol TPR produk alto

Lembar 2

Figure 4: Loafer Shoes.

\section{Pembuatan Desain Komputer \\ “DS 02 “}

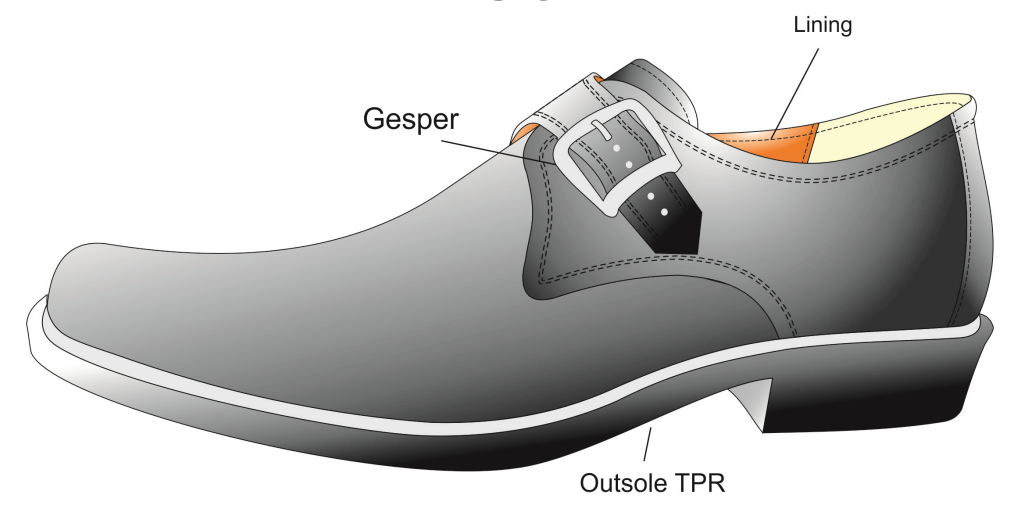

Spesifikasi desain " DS 02 " , antara lain :

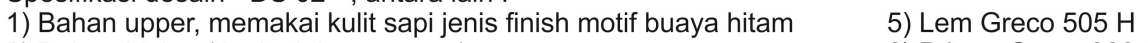

2) Bahan Lining ( lapis dalam sepatu )

6) Primer Greco $330 \mathrm{~A}$

- Bagian depan kain kaos

- Bagian samping memakai imitasi sofi warna kuning jahe

7) Tamsin ( Plat besi )

- Bagian belakang memakai bahan imitasi diping

8) Benang warna hitam ukuran 40

3) Bahan insole

- Bagian atas texson dengan lapis kain kaos

- Bagian bawah keras TW

- Bagian alas sepatu memakai bahan sofi dilaminating

spon agar lebih lembut dan nyaman

4) Outsole memakai jenis sol TPR produk alto

Lembar 2

Figure 5: Monk Strap shoes. 
Figure 5 shows a monk strap shoe with design specifications that are used to communicate emerging ideas so that they can be easily understood by the user before being made a prototype. Instead of a shoelace a single hook is used.

\section{Pembuatan Desain Komputer “ DS 08 “}

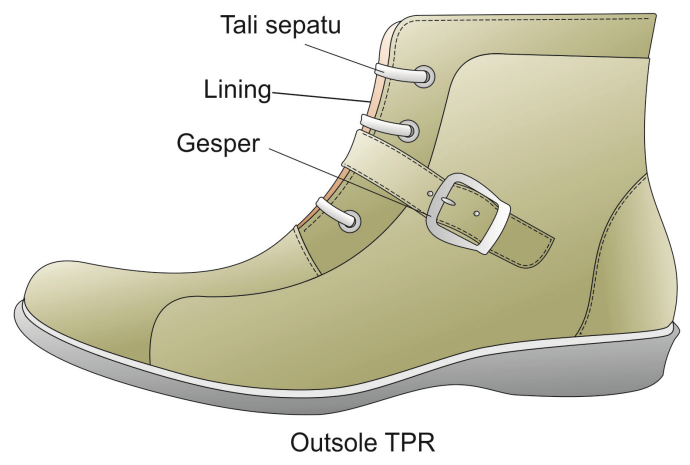

Spesifikasi desain "DS 01 ", antara lain :

1) Bahan upper, memakai kulit sapi jenis finish warna olive

5) Lem Greco $505 \mathrm{H}$

2) Bahan Lining ( lapis dalam sepatu )

6) Primer Greco 330 A

- Bagian depan kain kaos

- Bagian samping memakai bahan busa teri

7) Tamsin ( Plat besi )

3) Bahan insole

- Bagian atas texson dengan lapis kain kaos

8) Benang warna hijau ukuran 40

- Bagian bawah keras TW

- Bagian alas sepatu memakai bahan sofi dilaminating

spon agar lebih lembut dan nyaman

4) Outsole memakai jenis sol TPR produk alto

Figure 6: Boots.

Figure 6 shows a monk strap shoe with design specifications that are used to communicate emerging ideas so that they can be easily understood by the user before being made a prototype. Instead of a shoelace a single hook is used.

\section{Discussion}

Loafers (Figure 1) can be used for semi-formal events and casual events. If you are going to choose one that is semi-formal, choose loafers made from leather to make it look more elegant. As for the casual and casual impression, choose loafers with suede.

Usually, this shoe model does not have a shoelace so it is very practical, easy to use, no need to remove and tie shoelaces. However, there are also models of shoe loafers that use short straps and not along straps on sneakers. Loafers that use short straps are often called moccasins / boat shoes in the Table 2 .

There are two versions of the history of Loafers. The first version explains the shoes of this model, first introduced by Raymond Lewis Wildsmith in London in 1926. The 


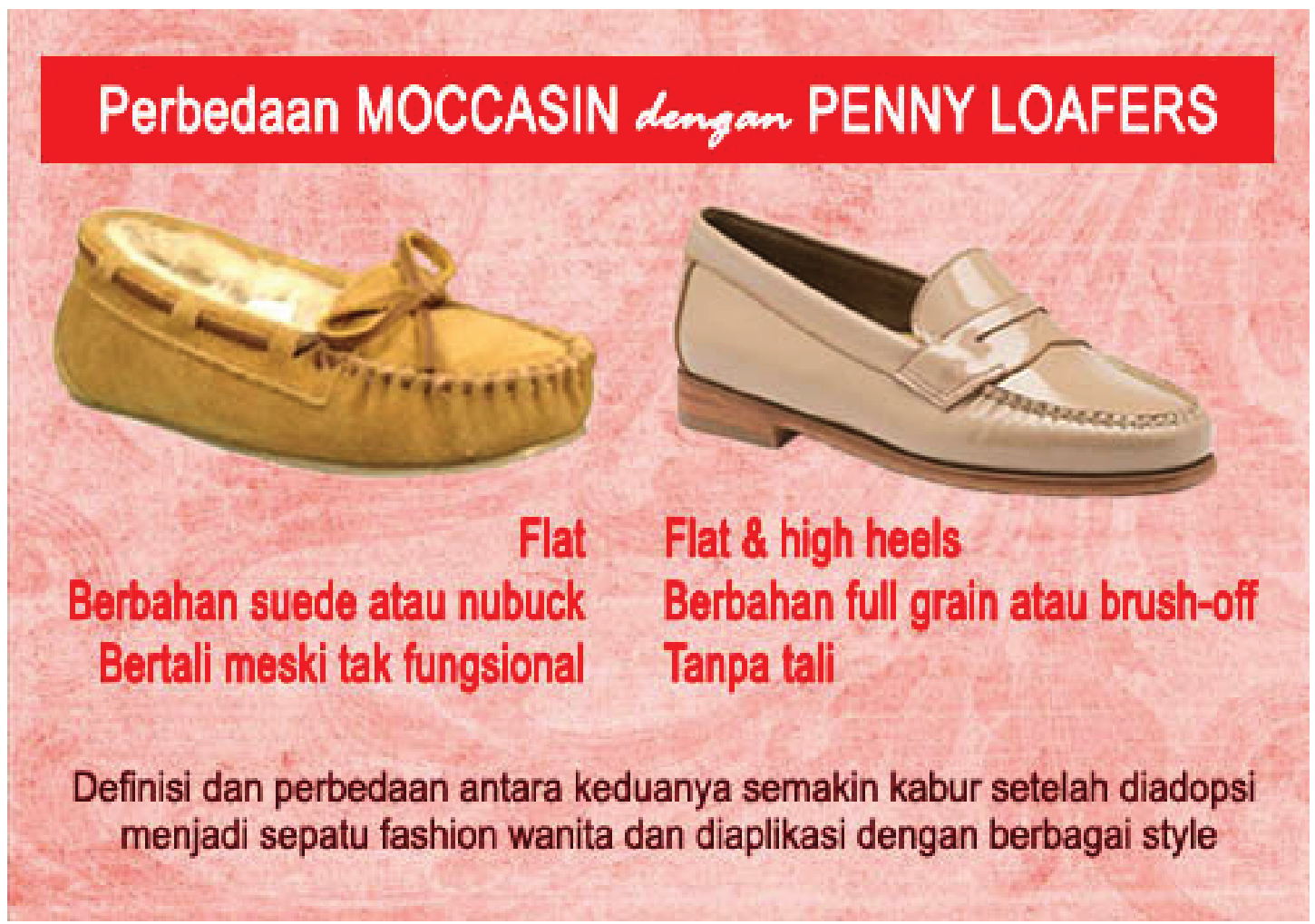

design of this shoe model to fulfill the orders of King George VI who wanted to use it in the palace environment as casual shoes.

Over time the shoe design was adopted by shoemakers and began to spread out of the palace. Even to reach America and known as Loafers. Until now, it is still done manually, even though the production of The Wildsmith Loafer has been carried out by modern technology machines. The reason is that the quality of shoes is maintained as since the company was founded in 1847 by Matthew and Rebecca Wildsmith, greatgrandson of Raymond.

The second version of the history of Loafers was first introduced as a new design by Nils Gregoriusson Tveranger in Aurland, Norway in 1930 with the name "Aurland Moccasin". This typical Indian shoe inspiration, then renamed "Aurland Shoes".

Loafers shoes with the name "Aurland Shoes" are produced in large quantities and are marketed to countries in Europe. After being popular in Europe, it was then brought to America. The promotion was carried out through Esquire Magazine with a Norwegian model wearing Loafers and showing the background of the life of Norwegian people.

Characteristics of monk strap shoes (Figure 2) are almost the same as oxford shoes. The difference is that monk strap shoes are more practical and easy to wear because 
they don't wear shoelaces. Instead, monk strap shoes use a buckle or hook belt on the front of the shoe.

With an exclusive and elegant impression, monk strap shoes are suitable for formal activities. Leather or black monk strap shoes are a favorite for executives and professionals to make them look more convincing.

At first, this model of footwear was used by monks, because the model was simple (not using a rope). The design covers the legs so that the Monk Strap is considered more able to protect the legs when used for activities than sandals that are usually worn by monks.

In general, boots (Figure 3) are used by soldiers when they are training and facing enemies on the battlefield. With the development of the fashion world, boots evolve so that it can be worn by anyone. Models of boots also develop with a variety of shapes, sizes and colors.

Now, boots are commonly used by young people and adults for semi-formal activities or casual time. The impression caused by boots users is masculine, manly and macho.

\section{Conclusion}

Drawing design can be done through three stages. First find references. Second, make an analogy image and the last is evaluation. References can be obtained by browsing the web, journals and by looking directly at the mall or boutique. An analogy drawing is done with the CoreIDRAW program to draw models of loafer shoes, monk strap shoes and boots.

\section{Funding}

This work was supported by applied research universities of Ministry of Research, Technology and Higher Education Republic of Indonesia under Grand No. 013/UCLPPM/KP-MULTI/III/2019.

\section{Acknowledgement}

I would like to thank to my colleague for their contribution and support to the research. I am also thankful to all the reviewers who gave thier valuable inputs to the manuscript and helped in completing the paper. 


\section{Conflict of Interest}

I has no conflict of interest to declare

\section{References}

[1] Lawson, Bryan. 1994. With Desing in Mind. Butterworth.

[2] Graves, Michael. 1977. The Necessity for Drawing Tangible Speculation, Architectural Design, Vol. 6/77: 384 - 394

[3] Herbert, Daniel M. 1993. Architectural Study Drawing. New York: Van Nostrand Reinhold.

[4] Schon, D. A. And Wiggins, G. 1992. Kinds of Seeing and Their Function in Designing, Design Studies, Vol. 13/2: 135 -- 156.

[5] Goldschmidt, Gabriela. 1991, The Dialectics of Sketching, Creativity Research Journal, Vol 4/2: 123 -- 143.

[6] Yi Ellen, Luen Do dan Mark D. Gross. 1996. Drawing as a Means to Design Reasoning, Artificial Intelligence in Design 96. Workshop on Visual Representation in Stanford University.

[7] https://highlight.id/jenis-macam-model-desain-sepatu-pria-cowok-ngetrendtrendy-fashionable-ngehits-sekarang/

[8] http://www.tips-sepatu-wanita.com/2015/04/sepatu-model-loafers.html 